\title{
Influence of Japanese brome on western wheatgrass yield
}

\author{
MARSHALL R. HAFERKAMP, R.K. HEITSCHMIDT, AND MICHAEL G. KARL
}

\begin{abstract}
Authors are rangeland scientist, supervisory rangeland scientist, and postdoctoral rangeland scientist, respectively, USDA-ARS, Fort Keogh Livestock and Range Research Laboratory, Miles City, Mont. 59301.
\end{abstract}

\begin{abstract}
Japanese brome (Bromus japonicus Thunb.) has invaded many northern mixed-prairie plant communities. Understanding interactions of population dynamics of this and associated species is critical for proper management of communities infested with this annual. Objectives of this study were to determine the effect of Japanese brome removal on aboveground forage production and daily plant water relations of western wheatgrass [Pascopyrum smithii Rydb. (Love)] and Japanese brome in a western wheatgrass dominated northern mixed grass prairie community. During early spring of 1991, a wet year, and 1992, a dry year, 2 treatments, undisturbed and complete (total) removal of Japanese brome seedlings, were applied by hand at silty clay loam and clay field sites in circular, $1-\mathrm{m}^{2}$ quadrats. Vegetation in additional quadrats was left undisturbed or Japanese brome was removed to assess plant water relations at each site in 1992. Total standing crop was reduced $500 \mathrm{~kg} \mathrm{ha}^{-1}$ with removal of Japanese brome, while standing crop of western wheatgrass was increased $220 \mathrm{~kg} \mathrm{ha}^{-2}$ with Japanese brome removal. Increased standing crop of western wheatgrass appeared to result from increased tiller density of 153 tillers $\mathrm{m}^{-2}$ rather than increased weight per tiller. Western wheatgrass water relations were essentially unaffected by Japanese brome removal in 1992. Removal of Japanese brome from Northern Great Plains plant communities may increase production of associated perennial grasses, but managers should also expect a short-term decrease in total standing crop.
\end{abstract}

Key Words: Bromus japonicus, pascopyrum smithii, Northern Great Plains

Invasion of Japanese brome (Bromus japonicus Thunb.), an introduced weedy graminoid, into numerous mixed-prairie communities in the Northern Great Plains (Haferkamp et al. 1993, Whisenant 1990) may reduce forage production of perennial grasses and performance of grazers. Through competition for

The authors express appreciation to Bill Creamer, Bryon Bennett, Cheryl Murphy, and several summer aids for field assistance, Mary Ellen French for assistance with graphics, and Dr. Michael MacNeil for assistance with statistical analyses.

This paper is a contribution from the USDA/ARS and Montana Agricultural Experiment Station, Miles City, Mont.

USDA/ARS, Northern Plains Area, is an equal opportunity/affirmative action employer, and all agency services are available without discrimination.

Publication has been approved by the Director of the Montana Agr. Exp. Sta. Journal Ser. J-2946.

Manuscript accepted 13 Jan. 1996. water and nutrients, annual bromes may reduce forage production of associated perennials, such as western wheatgrass [Pascopyrum smithii Rydb. (Love)], through reduction in number (i.e. density) and/or size of tillers. For example, Rummell (1946) found competition from downy brome (Bromus tectorum L.) reduced plant height, number of tillers, foliage weight, as well as root weight and length of western wheatgrass transplants.

Annual bromes have been shown to compete with seedlings of perennial seeded grasses (Buman et al. 1988; Drawe and Palmblad 1977; Harris 1967, 1977; Reichenberger and Pyke 1990; Young and Evans 1973), and perennial plants the second year after secding (Andersen et al. 1990, Romo and Eddleman 1987). Several researchers have shown increases in forage yields of western wheatgrass when ranges were treated with burning (Gartner et al. 1986, 1978, Whisenant 1990) and herbicides (Currie et al. 1987) to reduce Japanese brome. Lewis et al. (1975) hypothesized that reductions of western wheatgrass forage yields in ungrazed and lightly grazed pastures at Cottonwood, S. Dak. in 1963 may have been due to lack of spring precipitation coupled with competition from Japanese brome.

Studies are lacking, however, that quantify the effect of removing Japanese brome seedlings without the effects of burning, herbicides, or grazing, treatments that can affect both perennial and annual grasses. Our study was designed to determine the effect of hand removing Japanese brome seedlings on annual aboveground forage production and daily water relations of western wheatgrass in a western wheatgrass dominated northern mixed grass prairie community without the influence of herbicides, burning, or grazing.

\section{Materials and Methods}

\section{Study Sites}

Research was conducted on the Fort Keogh Livestock and Range Research Laboratory $\left(46^{\circ} 22^{\prime} \mathrm{N} 105^{\circ} 5^{\prime} \mathrm{W}\right)$ near Miles City, Mont. Regional topography ranges from rolling hills to broken badlands with small intersecting ephemeral streams flowing into large rivers located in broad, nearly level valleys. Indigenous vegetation on the 22,500 -ha research station is a grama-needlegrass-wheatgrass (Bouteloua-Stipa-Agropyron) mix (Kuchler 1964). Annual precipitation averages $338 \mathrm{~mm}$, with about $60 \%$ received from April through September (NOAA 1982-90). Daily temperatures range from $>38^{\circ} \mathrm{C}$ during summer to $<-40^{\circ} \mathrm{C}$ during winter. The average frost-free growing season is $\mathbf{1 5 0}$ days.

Two study sites were located about $7 \mathrm{~km}$ apart. Topography of both sites ranged from gently sloping $(<2 \%)$ to level. Soils at the 
silty clay loam site were largely Kobar silty clay loams (fine, montmorillonitic, Borollic Camborthid). Soils at the clay site were primarily a composite of Absher heavy clays (fine, montmorillonitic, Borollic Natrargids) and Gerdrum clay pans (Borollic Natrargids). Vegetation at both sites was dominated by western wheatgrass, blue grama [Bouteloua gracilis (H.B.K.) Lag. ex Griffiths], Sandberg's bluegrass (Poa secunda Presl.), sand dropseed [Sporobolus cryptandrus (Torr.) Gray], and Japanese brome. Yellow sweet clover (Melilotus officinalis [L.] Lam.) was also present on the silty clay loam site in 1991.

Japanese brome seedlings were abundant by March of both years. In 1991, inflorescences emerged in May, seeds ripened in mid-June, and most plants were senesced by early July. Phenological development was similar in 1992; plants advanced from the 2 to 3-leaf stage to hard dough during the period from 15 April to 22 June. However, plants senesced slightly earlier (late June) in 1992 because of dry conditions. Western wheatgrass tillers began emerging in March and April both years. Tillers remained in the 4 to 6-leaf stage throughout the growing season, few produced inflorescences either year, and height of tillers at harvest averaged $37 \mathrm{~cm}$ in 1991 and $27 \mathrm{~cm}$ in 1992.

\section{Experimental Design and Methods}

Investigations were conducted at 2 sites in 2 years. Each study site encompassed about 0.1 ha and was chosen in spring based on ocular estimates of residual standing crop of Japanese brome and western wheatgrass. These standing crops were our best guides for potential species composition during the current growing season. Ten blocks were located within each site and year, each within a uniform stand of Japanese brome and western wheatgrass. Two circular, $1-\mathrm{m}^{2}$ quadrats were marked within each block, and treatments (1) undisturbed or (2) total Japanese brome seedling removal randomly assigned to quadrats. Emerging seedlings were removed by hand several times from mid April to early June in both 1991 and 1992. treatment blocks were installed at both sites in 1992 to assess plant water relations. Western wheatgrass tillers growing in the undisturbed and total-removal treatments and Japanese brome plants growing in the undisturbed treatment were monitored on 7 May, 8 June, and 22 June 1992 at the silty clay loam site and on 14 May, 10 June, and 24 June 1992 at the clay site. Xylem pressure potentials were determined at about 0430, 0830, 1230, 1630, and 2030 hours on the youngest fully-expanded leaf using standard pressure chamber techniques (Scholander et al. 1965). Stomatal conductance was measured on western wheatgrass tillers growing in the undisturbed and total removal plots at about 0930,1330 , and 1730 hours on the same days as xylem pressure potentials were determined. Conductance measurements on a given day were made on the youngest, fully-expanded leaf. Leaf area within the chamber was determined with a LI-COR ${ }^{1}$ LI-3000 portable area meter after measurements were completed. A LI$\mathrm{COR}^{1}$ LI-1600 steady state porometer, equipped with a cylindrical cuvette was used to measure stomatal conductance, ambient air temperature, and relative humidity. Photosynthetically active radiation was measured with a $\mathrm{LI}-\mathrm{COR}^{1}$ LI-190S-1 quantum sensor. Soil water content was determined gravemetrically for the 0 to 30,30 to 60 , and 60 to $90-\mathrm{cm}$ depths in undisturbed areas at both sites.

Height of 1 premarked western wheatgrass tiller, located near the center of all 30 treatment quadrats, was measured on 6 dates in 1992 between 15 April and 22 June. Heights were measured from the soil surface to the tip of the longest extended leaf.

\section{Statistical Analyses}

Analyses of variance were used to test the effect of years, sites, and removal treatments on all standing crop components and western wheatgrass tiller weights and densities (Table 1). Effects of years, sites, and their interaction were tested with the residual variation between blocks within year-site combinations (error a); effects of brome removal and interaction of removal treatments

Table 1. Degrees of freedom (df), mean squares (MS), and significance levels for AOV models used to statistically analyze standing crops and western wheatgrass tiller density and weight per tiller for 2 years, 2 sites, and 2 treatments.

\begin{tabular}{|c|c|c|c|c|c|c|c|}
\hline & \multirow[b]{2}{*}{ df } & \multicolumn{4}{|c|}{ Standing crops } & \multicolumn{2}{|c|}{ Western wheatgrass } \\
\hline & & Japanese brome & Total & $\begin{array}{c}\text { Total minus } \\
\text { brome }\end{array}$ & $\begin{array}{l}\text { Western } \\
\text { wheatgrass }\end{array}$ & Tiller density & $\begin{array}{l}\text { Weight } \\
\text { tiller }\end{array}$ \\
\hline Model & & MS & MS & MS & MS & MS & MS \\
\hline Year $(Y)$ & 1 & 32,854 & $2,578,051 * *$ & $2,028,845^{* *}$ & $291,949 *$ & $1,849,536^{* *}$ & $32.44 * *$ \\
\hline Site (S) & 1 & $830,607^{* * 1}$ & $2,680,438 * *$ & $526,825^{*}$ & 575 & $433,946^{*}$ & $6.78^{* *}$ \\
\hline $\mathbf{Y} * \mathbf{S}$ & 1 & $230,824 *$ & 3,100 & 180,424 & $1,242,611 * *$ & 118,272 & 0.41 \\
\hline Error a & 36 & 37,281 & 85,733 & 86,011 & 57,519 & 32,044 & 0.24 \\
\hline Treatment (R) & 1 & $11,802,932 * *$ & $5,391,581^{* *}$ & $1,240,020^{* *}$ & $971,876^{* *}$ & $470,018^{* *}$ & 0.03 \\
\hline $\mathbf{Y} * \mathbf{R}$ & 1 & 12,873 & 6,401 & 1,119 & 100,991 & $188,568^{* * *}$ & 0.09 \\
\hline $\mathrm{S} * \mathbf{R}$ & 1 & $751,401 * *$ & $810,192 * *$ & 1,107 & 6,394 & 53,045 & 0.16 \\
\hline $\mathbf{Y} * \mathbf{S} * \mathbf{R}$ & 1 & $191,258 * *$ & 3,672 & 141,928 & 14,301 & 19,096 & 0.03 \\
\hline Error $b$ & 36 & 36,899 & 76,745 & 43,686 & 39,062 & 19,397 & 0.22 \\
\hline
\end{tabular}

${ }^{1}$ Levels of significance *P $\leq 0.05 * * \mathrm{P} \leq 0.01$.

Standing crop and density measurements were made after Japanese brome matured in early July 1991 and late June 1992. Herbage was clipped to ground level in a circular, $0.25-\mathrm{m}^{2}$ quadrat located at the center of each circular, $1-\mathrm{m}^{2}$ treatment quadrat, oven-dried for 48 hours at $60^{\circ} \mathrm{C}$, and weighed. Density of western wheatgrass tillers was determined by counting within the same quadrat.

To assist in interpretation of standing crop data, 5 additional with year and site were tested with residual intra-block variation (error b). Regression analysis was used to examine the effect of Japanese brome standing crop on western wheatgrass standing crop and tiller density.

\footnotetext{
Tention of a trademark of proprietary product does not constitute a guarantee or warranty of the product by USDA-ARS and does not imply approval to the exclusion of other products that may also be available.
} 
Table 2. Degrees of freedom (df), mean squares (MS), and significance levels for tiller height, xylem pressure potential, and stomatal conductance of western wheatgrass for 2 sites and 2 treatments for 1992; and xylem pressure potentials of western wheatgrass and Japanese brome on undisturbed quadrats at both sites in 1992.

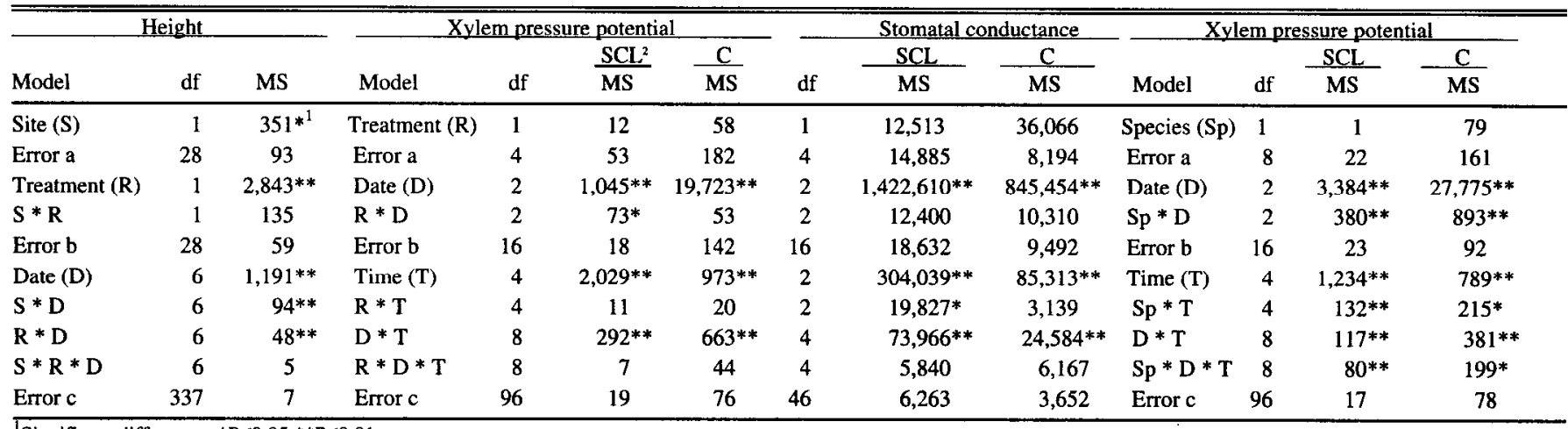

Significant differences *P $\leq 0.05 * * \mathrm{P} \leq 0.01$.

${ }^{2}$ Sites silty clay loam $(\mathrm{SCL})$ and clay $(\mathrm{C})$.

Analysis of variance was used to test effects of site, treatment, and date on western wheatgrass tiller height (Table 2). Effect of site was tested with the pseudo-replicate block within-site mean square (error a); effects of treatment and site by treatment interaction were tested with the block within site by treatment interaction mean square (error b); and effects of date and interactions of date with site and treatments were tested with residual inter-date mean square (error c).

Split-split-plot analyses of variance (Table 2) were used to test
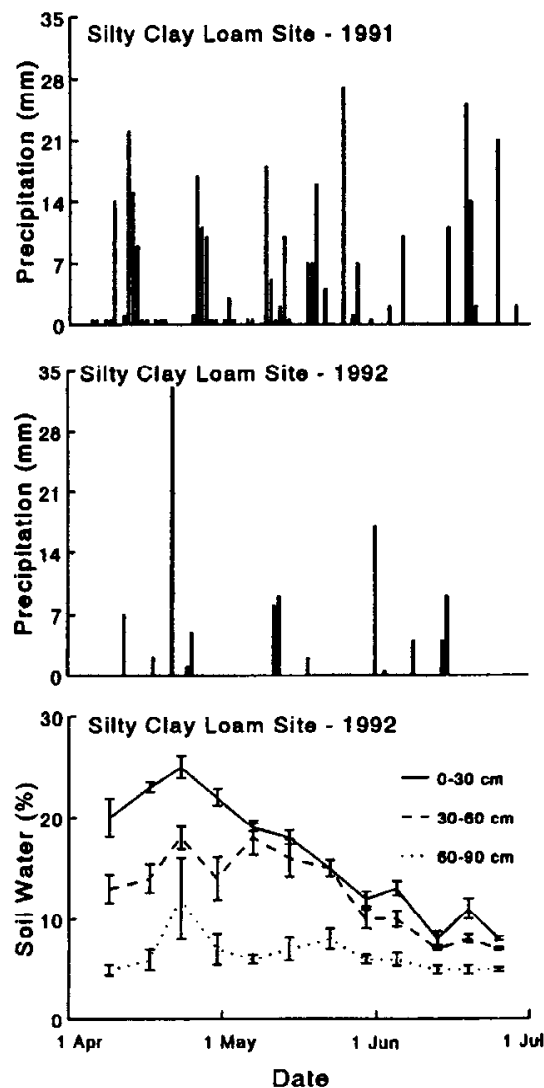

effects of removal treatment, date, and time on xylem pressure potential and stomatal conductance of western wheatgrass at each site separately. While a common experimental protocol was implemented at each site, sampling dates were not common to both sites and, hence, data from each site were analyzed separately. Effects of removal treatments were tested with block by treatment interaction mean square (error a); effects of date and treatment by date interaction were tested with residual inter-date mean square (error b); and effects of time and interactions of time with
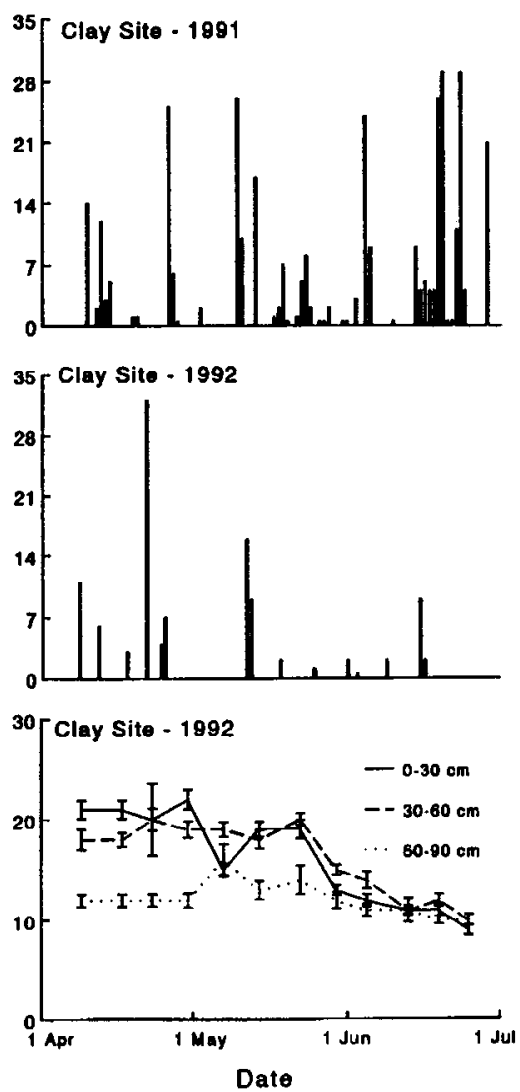

Fig. 1. Precipitation at the silty clay loam and clay sites during 1991 and 1992, and soil water content (means \pm standard errors) for both sites collected from undisturbed treatments in 1992. Because of failure of the automated weather station located at the clay site, precipitation data were supplemented with records from the Frank Wiley Airfield (NOAA 1991- 92) located about 11 km from the plots. 


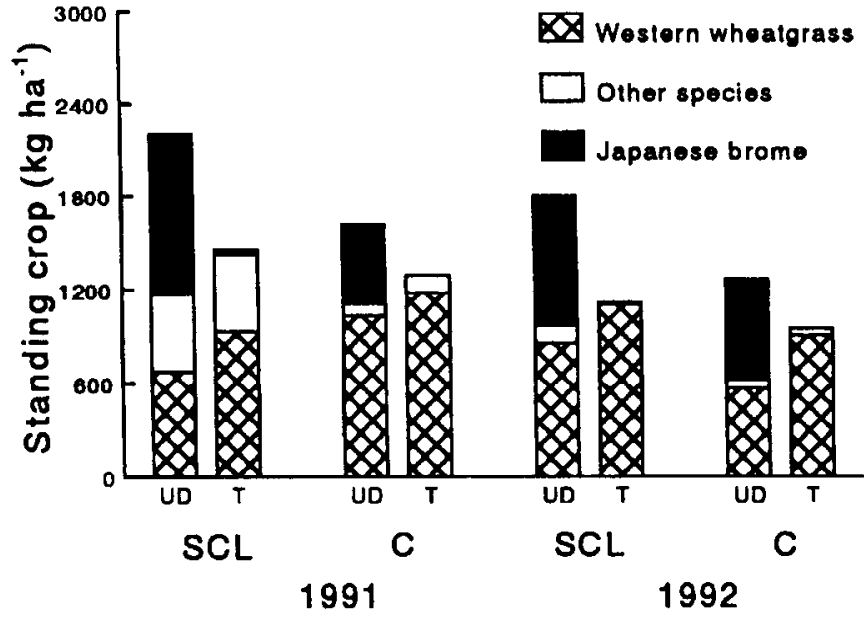

Fig. 2. Standing crops for Japanese brome, other vegetation, and western wheatgrass growing in undisturbed (UD) and total removal (T) plots on the silty clay loam (SCL) and clay (C) sites in 1991 and 1992.

treatments and dates were tested with residual intra-date mean square (error c). Analysis of variance was used to test the effects of plant species, date and time on xylem pressure potentials of western wheatgrass and Japanese brome in undisturbed plots (Table 2). Effect of species was tested with the pseudo-replicate block within species mean square (error a); effects of date and species by date interaction was tested with residual inter-date mean square (error b); and effect of time and interactions of time with species and date were tested with residual intra-date mean square (error c). In all analyses, means were separated by Fisher's Least Significant Difference procedure.

\section{Results and Discussion}

Differences between years in precipitation patterns and differences between sites in soil texture, and thus soil water dynamics, resulted in 4 different environments (Fig. 1). Precipitation in April, May, and June totaled $333 \mathrm{~mm}$ in 1991 and $101 \mathrm{~mm}$ in 1992 compared to the long-term 164-mm average (NOAA 19911992). Temporary dynamics of soil water in the 0 to $30-\mathrm{cm}$ and 30 to $60-\mathrm{cm}$ depths but not the 60 to $90-\mathrm{cm}$ depths of the soil profile were closely influenced by precipitation events in 1992. The rate and degree of seasonal decline in soil water was slightly greater at the silty clay loam than the clay site (Fig. 1). However, even at equal soil water contents, fine-textured particles (e.g. clay and silt), will exert greater forces of retention on water than larger particles (e.g. sand) because of their greater surface area per unit mass.

With removal of Japanese brome seedlings, standing crop of total vegetation was reduced, but total standing crop minus Japanese brome and western wheatgrass standing crop were increased (Table 3 and Fig. 2). These changes did not appear to be affected by variation in associated species or variations in growing season precipitation. Western wheatgrass tiller density increased with brome removal, but weight per tiller was unaffected by brome removal (Table 3). Rummell (1946) also reported competition from downy brome reduced the number of shoots produced by western wheatgrass rhizomes. Significant linear relationships were found when data for both western wheatgrass standing crop and tiller density were regressed against Japanese brome standing crop.

Standing crop ( $\left.0.25 \mathrm{~m}^{-2}\right): \mathrm{Y}=25.52-0.28 \mathrm{X} \mathrm{r}^{2}=0.20 \mathrm{P}<0.01$

Tiller density (Number $0.25 \mathrm{~m}^{2}$ ): $\mathrm{Y}=163.71-2.19 \mathrm{X} \mathrm{r}^{2}=0.16 \mathrm{P}<0.01$

The year effect detected on community dynamics was likely caused by variation in amount and distribution of rainfall, whereas the site effect may have simply been due to different soil textures (Tables 1 and 3). Standing crops were generally greater in

Table 3. Significant responses of a western wheatgrass dominated plant community to total removal of Japanese brome seedlings during 1991 and 1992 on a silty clay loam (SCL) and clay (C) site.

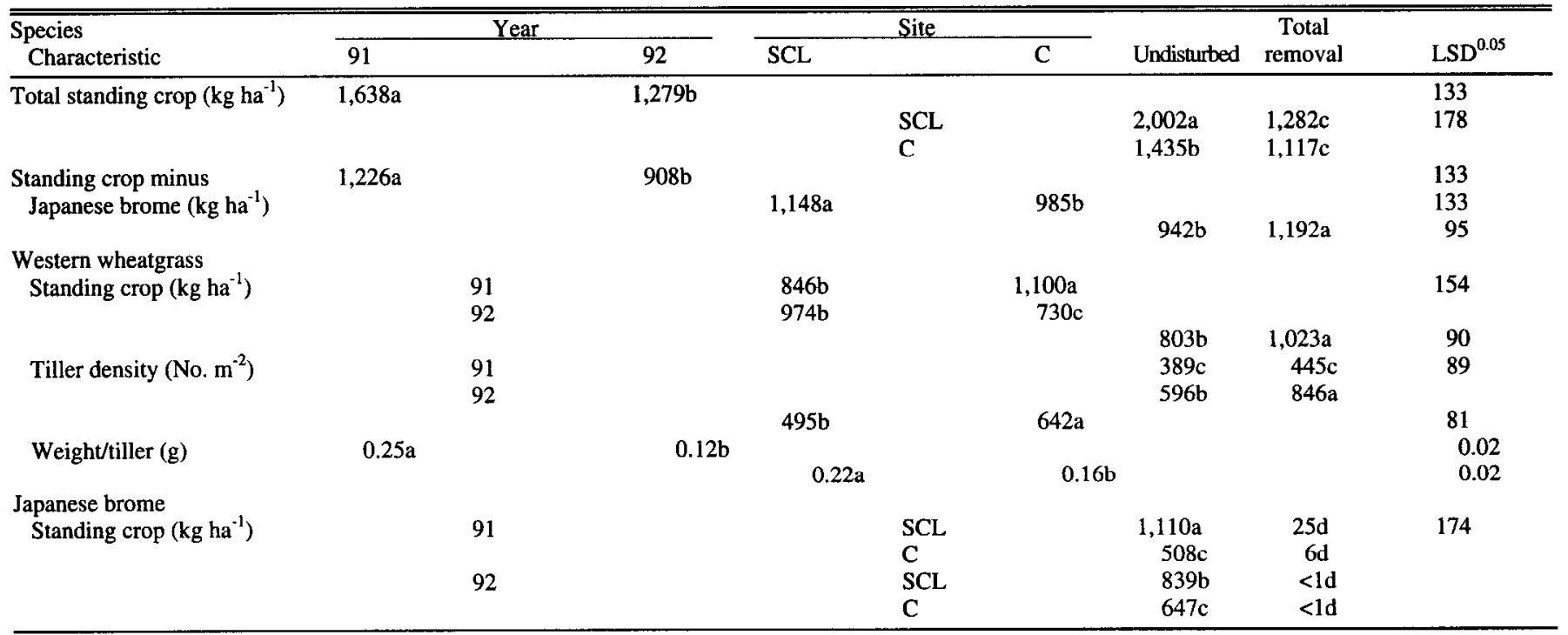

Means in rows or columns for each characteristic followed by the same letter are not significantly different at $\mathrm{P} \geq 0.05$. 
1991 than 1992 and greater on the silty clay loam than the clay site. One exception was that western wheatgrass standing crop was greatest on the clay site in 1991 and the silty clay loam site in 1992. Tiller density was consistently greater in 1992 than 1991 and greater on the clay than the silty clay loam site. In contrast, weight per tiller was greater in 1991 than 1992 and greater on the silty clay loam than the clay site. Greater fall precipitation was likely the cause for greater tiller density in 1992 than in 1991. Rainfall totaled $118 \mathrm{~mm}$ in September, October, and November 1991 compared to $24 \mathrm{~mm}$ in fall 1990 . We have observed new western wheatgrass tillers emerging during falls with above average precipitation. Tiller weight, however, would have benefited more from the $333 \mathrm{~mm}$ rainfall that occurred in April, May, and June 1991 compared to $155 \mathrm{~mm}$ rainfall during the same period in 1992.

The reduction in total forage standing crop following early season removal of Japanese brome seedlings is in agreement with findings of others where burning (Gartner et al. 1978, 1986) and herbicides (Hewlett et al. 1981) were the methods of brome removal. After applying atrazine [2-chloro-4-(ethylamino)-6-(isopropylamino)-s-triazine], Hewlett et al. (1981) speculated that reduction in total forage production may have resulted from the adverse effect of atrazine on perennials. Herbicide, however, was not a factor interfering with production of perennial grasses in our study.

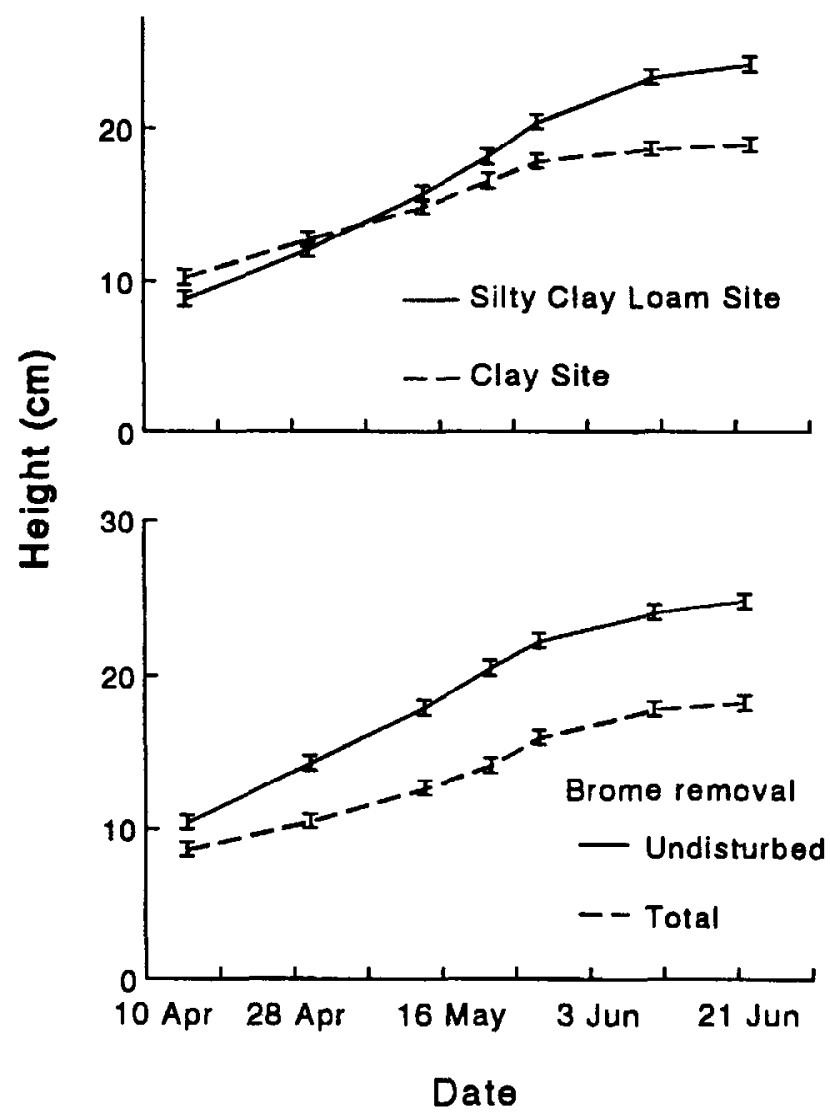

Fig. 3. Means \pm standard errors for heights of western wheatgrass tillers (significant site by date and treatment by date interactions) during 1992.
Forage production of perennial grasses and forbs did not increase adequately to compensate for loss of standing crop resulting from Japanese brome removal. This may have been a short-term phenomena. Eissenstat and Caldwell (1989) report that root growth into soil gaps allows plants to occupy a greater soil volume and soil microsites richer in resources. However, greater resource acquisition due to increased root volume (added resources) may not be immediately apparent. We do not know the extent of western wheatgrass rhizome and root growth into soil gaps where Japanese brome had been removed. Mueller (1941) reported that new rhizomes of western wheatgrass form concurrently with the shoots, provided there are adequate resources (e.g. carbohydrates, water, etc.) for growth.

Height of western wheatgrass tillers during 1992 was most affected by date and treatment, but some inconsistency in response resulted in significant site by date and treatment by date interactions (Table 2 and Fig. 3). Western wheatgrass tillers were shorter on the silty clay loam than clay site through late April and taller on this site thereafter. Maximum tiller height was similar in April for both removal treatments, but soon diverged with taller tillers occurring in undisturbed quadrats than with total removal (Fig. 3).

Reduction in maximum tiller height of western wheatgrass with removal of Japanese brome seedlings might have resulted from increased light or a phytochrome response to increased red light reaching western wheatgrass tillers. Casal et al. (1987) found both leaves and stems of annual ryegrass (Lolium multiflorum Lam.), smut grass [Sporobolus indicus (L.) R.Br.], and dallisgrass (Paspalum dilatatum Poir.) grew longer at higher far red:red ratios. Several authors have also reported amount of far red relative to red light increases within plant canopies in proportion to amount of green leaf material present (Casal and Smith 1989, Kasperhauer 1971, Kasperbauer and Karlen 1986).

Xylem pressure potentials and stomatal conductance for western wheatgrass were essentially unaffected by removal of Japanese brome seedlings (Table 2). One exception was the May collection on the silty clay loam site. Xylem pressure potential averaged $-1.64 \mathrm{MPa}$ in the undisturbed quadrats and -1.94 MPa in those where brome was removed. Allen (1982), however, reported stomatal resistances for western wheatgrass correlated well with decreases in biomass when western wheatgrass plants were grown with Russian thistle (Salsola kali L. var tenuifolia) in a greenhouse experiment.

Our study was not designed to determine if presence of Japanese brome decreased soil water content. Melgoza et al. (1990), however, found that downy brome reduced water resources around established plants of needle-and-thread (Stipa comata Trin. and Rupr.) and little rabbitbrush [Chrysothamnus viscidiflorus (Hook.) Nutt.]. Reduction in soil water resulted in more negative pressure potentials in the native species growing with downy brome than without. Potential increases in soil water that may have been realized through brome removal in our study could have been utilized through increased evaporation from the soil surface of the disturbed plots and/or increased growth and transpiration by western wheatgrass and other species.

Plant water stress increased as the growing season advanced and occurred earlier on the clay than the silty clay loam site (Fig. 4 and Table 2). By 10 June on the clay site, the midday xylem pressure potentials of western wheatgrass were only slightly more negative or equal to predawn pressure potentials. This phenomena occurs in western wheatgrass when leaves begin to roll and 

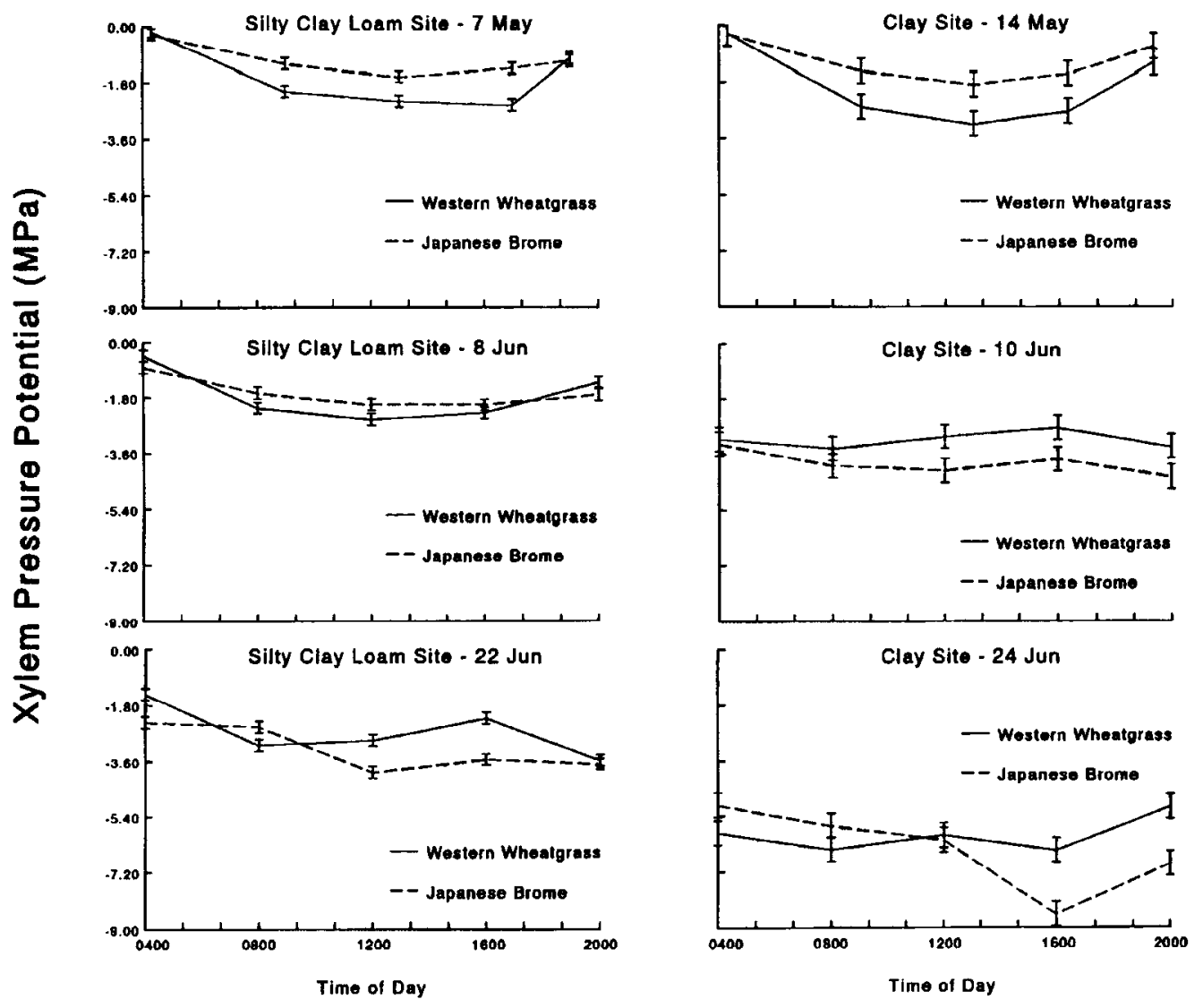

Fig. 4. Mean \pm standard errors for xylem pressure potentials of western wheatgrass and Japanese brome leaves (significant time-of-day by species interactions) from undisturbed plots for both the silty clay loam and clay sites in 1992. Data were analyzed by site.

leaf tips begin to senesce. A similar response was reported for Sandberg's bluegrass by Link et al. (1990). Generally, xylem pressure potentials of western wheatgrass were more negative than those of Japanese brome from 0800 to 1600 hours early in the growing season. However, when plant water stress increased, as noted by onset of the cyclic pattern, xylem pressure potentials of Japanese brome were most negative. This shift reflects advancing senescence of Japanese brome. Stomatal conductance of western wheatgrass followed a pattern similar to xylem pressure potentials, declining as the growing season advanced and declining more rapidly on the clay than the silty clay loam site (data not shown).

\section{Conclusions and Management Implications}

Standing crop of western wheatgrass was increased $200 \mathrm{~kg} \mathrm{ha}^{-1}$ with removal of Japanese brome, although the impact was not detected in plant water relations measured during the dry year 1992. The increase in forage appeared to result from an increase in tiller density and not an increase in weight per tiller. Tiller density was increased with an increase in fall precipitation, as well as removal of Japanese brome, which could have increased availability of spring soil moisture. Tiller weight increased with an increase in growing-season precipitation. The increase in western wheatgrass standing crop and reduction of total standing crop occurred regardless of variations in associated plant species or variation in growing-season precipitation. Increasing the clay content of soil and advancing plant phenology appeared to have a greater effect on western wheatgrass plant water relations than removal of Japanese brome.

Although removal of Japanese brome from Northern Great Plains rangelands will increase production of associated perennial grasses, it will also produce at least a short-term reduction in total forage production. Implementation of grazing management tactics and variation in environmental conditions will probably also influence this relationship.

\section{Literature Cited}

Allen, E.B. 1982. Water and nutrient competition between Salsula kali and two native grass species (Agropyron smithii and Bouteloua gracilis). Ecology 63:732-741.

Andersen, M.R., E.J. DePuit, R.H. Abernethy, and L.H. Kleinman. 1990. Suppression of annual bromegrasses by mountain rye on semiarid mined lands, p.47-55. In: E.D. McArthur, E.M. Romney, S.D. Smith, P.T. Tueller (compilers), Proceedings-Symposium on cheatgrass invasion, shrub die-off, and other aspects of shrub biology and management. USDA Forest Serv. INT Gen. Tech. Rep. INT-276. Ogden, Ut.

Buman, R.A., S.B. Monsen, and R.H. Abernethy. 1988. Seedling competition between mountain ryc, 'Hycrest' crested wheatgrass, and downy brome. J. Range Manage. 41:30-34. 
Casal, J.J. and H. Smith. 1989. The function, action, and adaptive significance of phytochrome in light-grown plants. Plant, Cell Environ. 12:855-862.

Casal, J.J., R.A. Sanchez, and V.A. Deregibus. 1987. The effect of light quality on shoot extension growth in three species of grasses. Ann. Bot. 59:1-7.

Currie, P.O., J.D. Volesky, T.O. Hilken, and R.S. White. 1987. Selective control of annual bromes in perenuial grass stands. J. Range Manage. 40:547-550.

Drawe, D.L. and I.G. Palmblad. 1977. Competition between Russian wildrye seedlings and four common weeds. J. Range Manage. 30:223-226.

Eissenstat, D.M. and M.M. Caldwell. 1989. Invasive root growth into disturbed soil of two tussock grasses that differ in competitive effectiveness. Functional Ecol. 3:345-353.

Gartner, F.R., E.M. White, and R.I. Butterfield. 1986. Mechanical treatment and burning for high quality range forage, p. 135-140. In: South Dakota Beef Report, Animal Range Sciences Dept., Agr. Exp. Sta., Coop. Ext. Serv., South Dakota State Univ., Brookings, S. Dak.

Gartner, F.R., R.I. Butterfield, W.W. Thompson, and L.R. Roath. 1978. Prescribed burning of range ecosystems in South Dakota, p. 687-690. In: Hyder, D.N. (ed.) Proc. 1st Int. Rangeland Cong. Soc. Range Manage., Denver, Colo.

Haferkamp, M.R., J.D. Volesky, M.M. Borman, R.K. Heitschmidt, and P.O. Currie. 1993. Effects of mechanical treatments and climatic factors on the productivity of Northern Great Plains rangelands. J. Range Manage. 46:346-350.

Harris, G. 1967. Some competitive relationships between Agropyron spicatum and Bromus tectorum. Ecol. Monog. 37:89-111.

Harris, G. 1977. Root phenology as a factor of competition among grass seedlings. J. Range Manage. 30:172-177.

Hewlett, D.B., J.R. Johnson, R.I. Butterfield, and V.K. Mosley. 1981. Japanese brome response to atrazine in combination with nitrogen fertilizer in the mixed prairie. J. Range Manage. 34:22-25.

Kasperbauer, M.J. 1971. Spectral distribution of light in a tobacco canopy and effects of end-of-day light quality on growth and development. Plant Physiol. 47:775-778.

Kasperbauer, M.J. and D.L. Karlen. 1986. Light-mediated bioregulation of tillering and photosynthate partitioning in wheat. Physiol. Plant. 66:159-163.
Kuchler, A.W. 1964. Potential natural vegetation of the conterminous United States. Amer. Geog. Soc. Spec. Pub. 36. Amer. Geog. Soc. N.Y.

Lewis, J.K., M. Haferkamp, J.R. Lacey, R. Gibbens, J. Herndon, and L. Blome. 1975. Effect of range condition on steer gains, p. 34-45. In: Cottonwood research station, Field Day, February 25, 1975, Proc. and Res. Reports. Animal Science Dept. Agr. Exp. Sta., Coop. Ext. Serv., South Dakota State Univ. Brookings, S. Dak.

Link, S.O., G.W. Gee, and J.L. Downs. 1990. The effect of water stress on phenological and ecophysiological characteristics of cheatgrass and Sandberg's bluegrass. J. Range Manage. 43:506-513.

Melgoza, G., R.S. Nowak, and R.J. Tausch. 1990. Soil water exploitation after fire: competition between Bromus tectorum (cheatgrass) and two native species. Oecologia 83:7-13.

Mueller, I.M. 1941. An experimental study of rhizomes of certain prairie plants. Ecol. Monogr. 11:165-188

National Oceanic and Atmospheric Administration. 1982-1990. Climatological data annual summary, Montana. 85-93:13.

National Oceanic and Atmospheric Administration. 1991-1992. Climatological data annual summary, Montana. 94-95:13.

Reichenberger, G. and D.A. Pyke. 1990. Impact of early root competition on fitness components of four semiarid species. Oecologia 85:159166.

Romo, J.T. and L.E. Eddleman. 1987. Effects of Japanese brome on growth of bluebunch wheatgrass, junegrass, and squirreltail seedlings. Recl. and Reveg. Res. 6:207-218.

Rummell, R.S. 1946. Some effects of competition from cheatgrass brome on crested wheatgrass and bluestem wheatgrass. Ecol. 27:159-167.

Scholander, P.F., H.T. Hammel, E.D. Bradstreet, and E.A. Hemmingsen. 1965. Sap pressure in vascular plants. Science 148:339-346.

Whisenant, S.G. 1990. Postfire population dynamics of Bromus japonicus. Amer. Midl. Natur. 123:301-308.

Young, J.A. and R.A. Evans. 1973. Downy brome-intruder in the plant succession of big sagebrush communities in the Great Basin. J. Range Manage. 26:410-415. 